\title{
Associative Helminthiasis and Protozoasis in Wild ARTIODactyl Animals of the Boreal Forest Subzone in Belarus
}

\author{
Vasilevich Fedor ${ }^{1}$, Kaplich Valery ${ }^{2}$, Yakubovsky Miroslav ${ }^{3}$ \\ ${ }^{1}$ Department of Parasitology and Veterinary Sanitary Examination, Faculty of Veterinary Medicine, Skryabin Moscow State Academy of \\ Veterinary Medicine and Biotechnology, Moscow, Russian Federation \\ ${ }^{2}$ Department of Tourism, Nature Management and Hunting, Faculty of Forestry, Belarusian State University of Technology, Minsk, Republic \\ of Belarus \\ ${ }^{3}$ Laboratory of Parasitology, Vyshelessky Institute of Experimental Veterinary Sciences, Minsk, Republic of Belarus
}

\section{Email address:}

rector@mgavm.ru (V. Fedor), kaplichVM@mail.ru (K. Valery), bievm.parasitology@tut.bv (Y. Miroslav)

\section{To cite this article:}

Vasilevich Fedor, Kaplich Valery, Yakubovsky Miroslav. Associative Helminthiasis and Protozoasis in Wild ARTIODactyl Animals of the Boreal Forest Subzone in Belarus. American Journal of BioScience. Vol. 6, No. 5, 2018, pp. 52-56. doi: 10.11648/j.ajbio.20180605.11

Received: December 7, 2018; Accepted: January 22, 2019; Published: February 20, 2019

\begin{abstract}
The studies were conducted to evaluate a comparative efficacy of broad - spectrum anthelminthics with an immunomodulatory effect used for animal dehelminthization on the basis of an epizootic situation in helminthiasis and protozoasis of wild artiodactyl animals of the northern forest subzone of Belarus. Helminthological and protozoological investigations were based on the methods generally accepted in parasitology. The data obtained show infestation of a wild boar with 14 species of helminths belonging to four classes (Trematoda, Cestoda, Nematoda, Acanthocephala); moose - with 13 helminth species from three classes (Trematoda, Cestoda, Nematoda) and one species of Eimeria from Sporozoa class; European roe deer - with 11 helminth species from three classes (Trematoda, Cestoda, Nematoda) and 1 species of Eimeria from Sporozoa class. In terms of species the helminths belonging to Nematoda class predominate in helminthocenosis. The most widespread helminthosis in wildespread helminthosis in wild boartis Metastrongylosis, in moose is Mecistociriosis, in European roe deer is Trichostrongylidosis. Four preparations for dehelminthization of wild animals under laboratory and field conditions were tested. They were «22\% fenbendazole granulate», «20\% tetramizole granulate», «Polyparacid», «Pentavet». It was established that Polyparacid and Pentavet having and immunostimulating effect are more effective than «22\% fenbendazole granulate» and « $20 \%$ tetramizole granulate» having an immunosuppressive.
\end{abstract}

Keywords: Helminthiasis, Protozoasis, Infestation, Dehelminthization, Antihelmintic Drugs

\section{Introduction}

In Belarus, the boreal forest subzone stretches across the Belorusian Land District and the uplands of Belarus' central watershed divide: Orsha Upland, Minsk Upland, Oshma Ranges, Orsha-Mogilev Plateau and the northern, most elevated part of Central Berezina Plain. The latter, located between Orsha and Minsk Uplands, is characterized by a harsher climate compared to the southern part of the plain adjacent to the Belorusian Forest District and has a characteristic landscape of the plains bordering the Forest District.
The study area is characterized by a high population density of wild artiodactyl animals [1-4] and a high degree of infestation by parasites [5-11].

\section{Method}

Ecological and parasitological studies of wild artiodactyl animals were conducted in 2012-2018 at 3 veterinary clinics (Braslavsky Lakes, Berezinsky Biosphere Reserve, Begomlsky Leskhoz) of the game ranches in 13 districts of the 
boreal forest subzone of Belarus and using a transect sampling method [1-2, 4].

498 samples of excrements, organs, and tissues collected from 119 killed animals were studied by applying recognized parasitology methods of study. In the statistical processing of the collected material in order to assess the parasitosis index, following indicators were used - infestation prevalence (IP) and infestation intensity (II).

\section{Result and Discussion}

Epizootic status of wild artiodactyl animal helminthiasis and protozoasis. Helminthological studies revealed the infestation of wild boars with 14 species of helminths belonging to 4 helminthocenosis (table 1) by the greatest number of species (9), followed by tapeworms (3 species), trematodes, and acanthocephales (one species each).

Table 1. Prevalence and intensity indices of helminth invasion of a wild boar in fall-winter period in the subzone of oak-dark coniferous forests (N=297).

\begin{tabular}{|c|c|c|c|c|}
\hline & Helminth species & Number of infested animals & Prevalence of invasion (\%) & Intensity of invasion, min-max \\
\hline & Class Trematoda Rudolphi, 1808 & & & \\
\hline 1 & Dicrocoelium lanceatum & 7 & 10,9 & $1-6$ \\
\hline \multicolumn{5}{|c|}{ Class Cestoda Rudolphi, 1808} \\
\hline 2 & Spirometra erinacei-europeaei, larvae & 34 & 26,8 & $1-27$ \\
\hline 3 & Taenia hydatigena, larvae & 6 & 4,7 & $1-4$ \\
\hline 4 & Echinococcus granulosus, larvae & 8 & 12,5 & $1-8$ \\
\hline \multicolumn{5}{|c|}{ Class Nematoda Rudolphi, 1808} \\
\hline 6 & Oesophagostomum dentatum & 38 & 12,9 & $1-49$ \\
\hline 7 & Globocephalus urosubulatus & 34 & 26,8 & $2-298$ \\
\hline 8 & Metastrongylus elongatus & 248 & 83,6 & $1-59$ \\
\hline 9 & Metastrongylus pudendotectus & 291 & 97,9 & $2-47$ \\
\hline 10 & Metastrongylus salmi & 181 & 61,1 & $1-40$ \\
\hline 11 & Ascaris suum & 53 & 17,8 & $1-6$ \\
\hline 12 & Physocephalus sexalatus & 15 & 11,8 & $3-98$ \\
\hline 14 & Macracanthorynchus hyrudinaceus & 5 & 1,7 & $1-4$ \\
\hline
\end{tabular}

In wild boars, the most widespread helminthiasis form is metastrongylosis with a infestation rate of $97.9 \%$ in adult animals and up to $100 \%$ in young animals. Metastrogylidae are represented by 3 species: Metastrongylus pudendotectus (Wostokow, 1905) (most common, IP 97.9\%, II from 2 to 47 worms per animal), Metastrongylus elongates (Dujardin, 1845) (IP 83.6\%, II 1-59 worms per animal), and Metastrongylus salmi (Gedoelst, 1923) (IP 61.1\%, II 1-40 worms per animal). From one to three Metastrongylidae species were found in a single wild boar individual. The share of infested animals in the population is the largest in the fall-winter period (up to $97.9 \%$ ). By spring, the infestation percentage drops due to non-infested young animals and some adult wild boars getting naturally dewormed. In summer, IP rises to $78.2 \%$. In winter, the Metastrongylidae infestation level is the highest and constant, as the wild boar no longer feeds on earthworms. By the end of winter, the Metastrongylidae infestation figures reduce significantly, and by the spring, infestation prevalence and intensity levels are the lowest. In summer, there is a sharp increase in wild boar infestation due to larval Metastrongylidae invasion from earthworms and a minor growth by fall. At the same time, in summer, the wild boar develops immunity, which prevents large numbers of Metastrongylidae from entering the lungs, and they stay in the lymphatic system. By winter, resistance decreases, the wild boar's health is weakened, larvae invade the lungs from the lymph nodes, and the infestation curve rises sharply. The intensity of infestation by these species can be regarded as low: 1 to 59 Metastrongylus elongatus worms per host animal have been recorded.
Of other helminthiasis types, the prevalence of infestation with Trichocephalus and Globocephalus is high $-34.4 \%$ and $26.8 \%$, respectively. The intensity of infestation with Globocephalus was an order of magnitude higher than that with other species and was up to 298 worms per host animal. Of the tapeworm species, sparganosis pathogens, larvae of Spirometra erinaceieuropaei (Rudolphi, 1819) were quite common with a low infestation intensity (IP 26.8\%, II 1-27 worms per animal). Such frequent occurrence of sparganosis pathogens is more common in the south of Belarus, where favorable conditions exist for this helminth [1]. Other helminth species were much less common.

Assessment of the parasitological status of the wild boar habitats revealed that five intermediate Metastrongylidae hosts - earthworms - are infested with helminth larvae: Dendrobaena octaedra, D.rubidus, Allolobophora caliginosa, Lumbricus terrestris, L. rubellus (table 2). The overall average infestation rate was $17.3 \%$ in all collected worms, with an average infestation intensity of 25.8 larvae per earthworm. The maximum infestation intensity was 178 larvae. Earthworm infestation with Metastrongylidae larvae was the highest in mixed forests of coniferous and small-leaved deciduous tree species, where infestation prevalence ranged from $20.1 \%$ to $37.5 \%$ with an average of $28.8 \%$, and in floodplain meadows (IP 19.4-28.0\% with an average of $23.7 \%$ ). Same biotopes had the highest infestation intensities of Lumbricidae - 40.1 and 37.4 larvae per worm, respectively. A lower degree of infestation was recorded in worms collected in alder forests (IP 17.2-22.4\%, with an average of $19.8 \%$ ) and spruce forests (IP 7.5-13.3\%, with an 
average of $10.4 \%$ ), the lowest was observed in pine forests (IP $\quad 2.9-5.1 \%$, with an average of $4.0 \%$ ).

Table 2. Specific composition of earthworms and their infestation with Metastrongylidae in the biotopes of the boar habitat.

\begin{tabular}{|c|c|c|c|c|}
\hline Biotope & Earthworm species & $\begin{array}{l}\text { Mean density of } \\
\text { lumbricides in biotope, } \\
\text { specimen } / \mathbf{m}^{2}\end{array}$ & $\begin{array}{l}\text { Mean } \\
\text { prevalence of } \\
\text { invasion, \% } \\
\end{array}$ & $\begin{array}{l}\text { Mean intensity of } \\
\text { invasion, } \\
\text { specimen/species }\end{array}$ \\
\hline Pine forests & $\begin{array}{l}\text { Dendrobaena octaedra, Lumbricus rubellus, } \\
\text { Dendrobaena octaedra, }\end{array}$ & 0,7 & 4,0 & 8,2 \\
\hline Spruce forests & $\begin{array}{l}\text { Octolasium lacteum. } \\
\text { Allolobophora caliginosa, Dendrodrilus rubidus }\end{array}$ & 5,4 & 10,4 & 11,2 \\
\hline $\begin{array}{l}\text { Mixed coniferous - } \\
\text { small leaved forests }\end{array}$ & $\begin{array}{l}\text { Dendrobaena octaedra Allolobophora caliginosa, } \\
\text { Octolasium lacteum, } \\
\text { Lumbricus terrestris, } \\
\text { Lumbricus rubellus, }\end{array}$ & 17,1 & 28,8 & 40,1 \\
\hline Alder forests & $\begin{array}{l}\text { Dendrobaena octaedra Dendrodrilus rubidus } \\
\text { Allolobophora caliginosa, } \\
\text { Lumbricus terrestris, } \\
\text { Lumbricus rubellus, } \\
\text { Octolasium lacteum. }\end{array}$ & 20,3 & 19,8 & 32,1 \\
\hline Floodplain meadows & $\begin{array}{l}\text { Dendrobaena octaedra Allolobophora caliginosa, } \\
\text { Octolasium lacteum, } \\
\text { Lumbricus rubellus, } \\
\text { Lumbricus terrestris, }\end{array}$ & 11,2 & 23,7 & 37,4 \\
\hline On average foe subzone & & 10,9 & 17,3 & 25,8 \\
\hline
\end{tabular}

13 helminth species belonging to 3 classes (Trematoda, Nematoda, Cestoda) and 1 eimeria species belonging to the Sporozoa class were observed in moose (table 3). Nematodes are represented in the helminthocenosis by the greatest number of species (11), followed by tapeworms and trematodes (one species each). In moose, the most common helminthiasis types are mecistocirrosis, with an infestation rate of up to $86.1 \%$ in adult animals and up to $97 \%$ in young animals, and strongyloidosis (IP 75.6\%, II 9-91 worms per animal).

Table 3. Indices of helminth and Protozoa infestation prevalence and intensity in moose in the subzone of oak-dark coniferous forests $(N=115)$.

\begin{tabular}{|c|c|c|c|c|}
\hline & Helminth species & Number of infested animals & Prevalence of invasion (\%) & Intensity of invasion, min-max \\
\hline & Class Trematoda, Rudolphi,1808 & & & \\
\hline 1 & Fasciola hepatica & 24 & 20,8 & $3-24$ \\
\hline \multicolumn{5}{|c|}{ Class Nematoda, Rudolphi, 1808} \\
\hline 2 & Trichocephalus skrajbini & 18 & 15,6 & $4-15$ \\
\hline 3 & Cooperia oncophora & 9 & 7,8 & $1-3$ \\
\hline 4 & Oesophagostomum venulosum & 32 & 27,8 & $7-46$ \\
\hline 5 & Strongyloides papillosus & 87 & 75,6 & 9-91 \\
\hline 6 & Haemonchus contortus & 11 & 9,6 & $2-14$ \\
\hline 7 & Nematodirus spathiger & 5 & 4,3 & $1-2$ \\
\hline 8 & Nematodirus filicollis & 17 & 14,7 & 3-19 \\
\hline 9 & Bunostomum trigonocephalum & 4 & 3,4 & $1-2$ \\
\hline 10 & Gongylonema pulcarum & 20 & 17,4 & $4-15$ \\
\hline 11 & Mecistocirus digitatus & 99 & 86,1 & $7-94$ \\
\hline 12 & Ostertagia orlaffi & 6 & 5,2 & $1-2$ \\
\hline \multicolumn{5}{|c|}{ Class Cestoda, Rudolphi,1808 } \\
\hline 13 & Echinococcus granulosus larvae & 3 & 2,6 & $1-2$ \\
\hline \multicolumn{5}{|c|}{ Class Sporozoa, Leuckart, 1879} \\
\hline 14 & Eimeria zuernii & 4 & 3,5 & $21-29$ \\
\hline
\end{tabular}

Of the other helminthiases, high prevalence of esophagostomosis, fasciolasis, gongylonemosis, and trichocephalic infestations was observed $-27.8 \%, 20.8 \%$, $17.4 \%$, and $15.6 \%$, respectively. The intensity of infestation with Oesophagostomum was an order of magnitude higher than that with other species and was up to 46 worms per host animal. Less frequent were Ostertagia (IP 5.2\%, II 1-2 worms), Nematodirus (IP 4.3\%, II 1-2 worms), and Bunostomum (IP $3.4 \%$, II 1-2 worms).

The cestode class is represented by the causative agent of echinococcosis - Echinococcus granulosus larvae (Batsch, 1786) with a low infestation intensity (IP 2.6\%, II 1-2 worms).
Such frequent occurrence of echinococcosis pathogens is more common in the south of Belarus, where favorable conditions exist for this helminth. A single moose had simultaneously from 1 to 3 helminth species. A low infestation intensity was observed with the causative agent of eimeriosis - Eimeria zuemii (Nenez, 1989) (IP 3.5\%, II 21-29 worms).

The highest species diversity (table 4 ) was found in young pine stands (6 to 8 species), the lowest - in aspen ( 3 species) and common alder stands (3) and abandoned farmland (1). In the examined biotopes, Mecistocirus digitatus (Linstow, 1906; Raillet et Henry, 1912), Strongyloides papillosus (Weld, 1856), and Trichocephalus skrajbim (Baskakow, 1924) dominated. 
Echinococci and Eimeria were less common. Infestation prevalence was the highest in young pine stands $(7-13.1 \%)$ and mixed spruce stands (4.7-7.9\%) and the lowest on abandoned farmland (1.1-1.9\%) and in aspen stands (2.1-3.2\%).

Table 4. Indices of helminth and Protozoa infestation in moose in the territory GPU NP «Braslavsky Lakes», GPU «Berezinsky Biosphere Reserve» and GLKHU «Begomlsky Leskhoz».

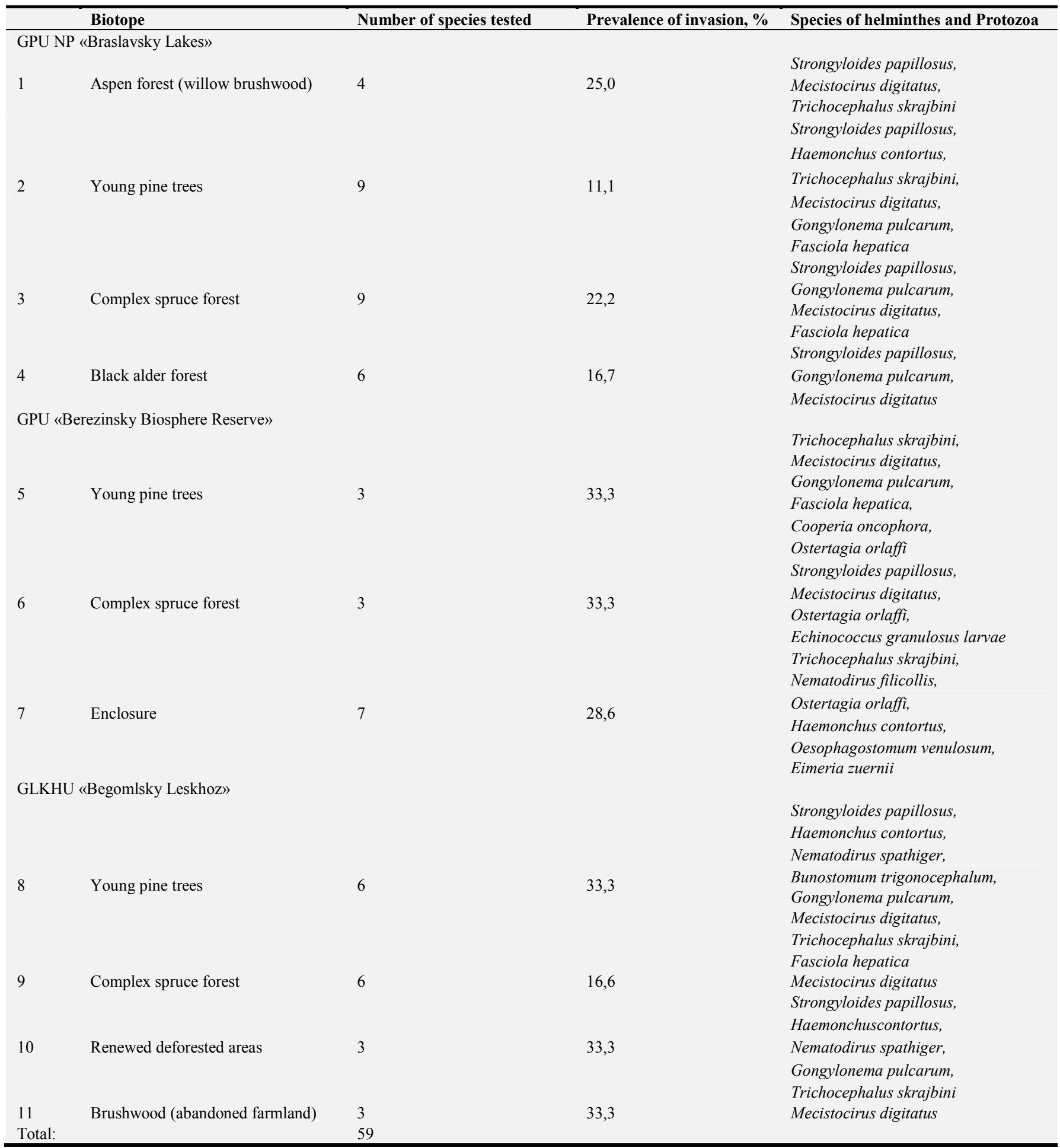

In European roe deer, the most often observed species is Chabertia (73.1\%); in $60.9 \%$ of the animals Trichocephalus, Oesophagostomum, and Bunostomum (26.6\%) have been observed simultaneously. A health species in $74.2 \%$ of the population.
Parasitosis prevention in wild artiodactyl animals. Based on a study of the properties of existing anthelmintics, timbendazole (22\% fenbendazole granulate) and the new preparation «Polyparacid» - a complex broad-spectrum anthelmintic with an immunomodulatory effect - were chosen 
for trials on wild boar feeding sites.

Trials on experimental sites demonstrated that $22 \%$ timbendazole at $45 \mathrm{mg} / \mathrm{kg}$ and the new preparation «Polyparacid» at $50 \mathrm{mg} / \mathrm{kg}$, when administered with food to groups of animals for 2 consecutive days as a treatment of metastrongylosis and associative helminthiasis of the gastrointestinal tract in wild boars, had a therapeutic efficacy of $97-100 \%$.

The efficacy of «Polyparacid» when administered to wild boars as a single dose with feed in a real-life setting was 96.2 in ascaridosis, $88.6 \%$ in trichocephalosis, $100 \%$ in oesophagostomy and metastrongylosis.

The new preparation «Pentavet» - a complex broad-spectrum anthelminthic with an immunomodulatory effect - was chosen for trials on feeding sites and in enclosures to compare it with $20 \%$ tetramizole granulate and thymbendazole ( $22 \%$ fenbendazole granulate).

Trials of the selected drugs on experimental sites demonstrated that $22 \%$ thymbendazole at $50 \mathrm{mg} / \mathrm{kg}$ and the new preparation «Pentavet» at $50 \mathrm{mg} / \mathrm{kg}$, when administered as a single to moose with fodder, bread (in enclosures), and salt bricks with aspen wood (Figure 1) as a treatment of mecistocirosis, nematodirosis, trichocephalosis, and monisiosis, had a therapeutic efficacy of $90-100 \%$.

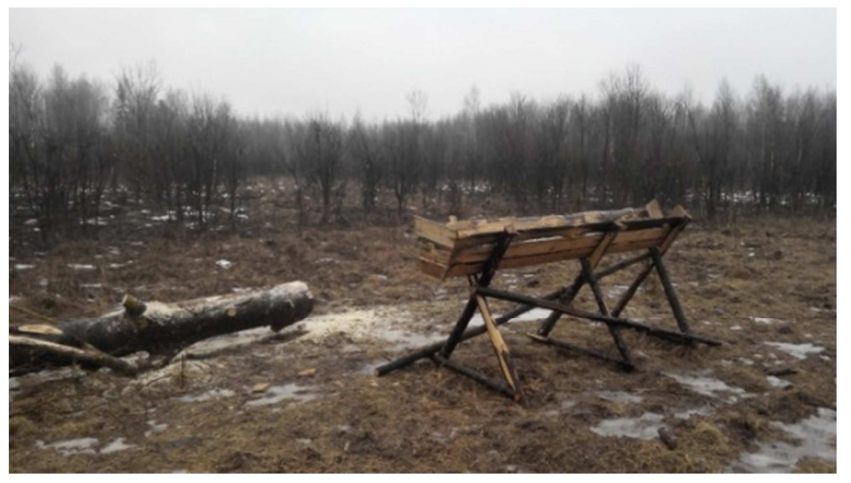

Figure 1. Feeding site for mooses in Begomlsky Leskhoz.

Parasitological studies of «Pentavet» in a real-life setting showed that its efficacy when administered to moose as a single dose with feed was $100 \%$ in mecistocirosis and nemotodirosis, $98.5 \%$ in trichocephalosis, and $100 \%$ in mecistocirosis and monisiosis at Berezinsky Biosphere Reserve.

\section{Conclusions}

Helminthological and protozoological investigation revealed wild boar infestation with 14 helminth species belonging to four classes; moose - with 13 helminth species from three classes and one species of Eimeria; European roe deer - with 11 helminth species from three classes and 1 species of Eimeria. In terms of species the helminths belonging to Nematoda class predominate in helminthocenosis. The most widespread helminthosis in wildespread helminthosis in wild boartis Metastrongylosis, in moose is Mecistociriosis, in European roe deer is Trichostrongylidosis.

It was established that the anthelminthics «Polyparacid» and «Pentavet» administered with food one time to groups of wild artiodactyl animals at the dose of $50 \mathrm{mg} / \mathrm{kg}$ in parasitoses showed $90-100 \%$ therapeutic efficacy. Besides these new complex preparations have an immunostimulating effect. As to $« 22 \%$ fenbendazole granulate», $« 20 \%$ tetramizole granulate». They have an immunosuppressive effect.

We think that in future anti-parasitic measures should be taken with application of anthehelminthics with an immunomodulating effect.

\section{References}

[1] Anisimova E. I., Penkevich V. A. Helminthofauna of wild hoofed animals in Belarus. - Minsk: Belaruskaya Navuka, 2016. $-241 \mathrm{pp}$

[2] Vasilevich F. I., Kaplich V. M., Yakubovsky M. V., Bakhur O. V. // M: Russian parasitological gournal, 2017. - T. volume 41, issue. 3. - pp. 246-248.

[3] Kaplich V. M., Yakubovsky M. V., Bakhur O. V. // Proceedings of the International Sciencetific and Research Conference dedicated to on the $95^{\text {th }}$ Anniversary of Parasitology, Veterinary and Public Health Examination Department, November 11-13, 2015. - Moscow: Skryabin MSAVMB. - pp. 77-80.

[4] Kaplich V. M., Yakubovsky M. V., Bakhur O. V. // Minsk: Ecology and Animal World, 2016. - №2. - pp. 33-35.

[5] Kaplich V. M., Yakubovsky M. V., Bakhur O. V. // Collected These of Reports of the81st International Scientific and Practical Conference, Febriary 2017 [electronic resource].-Minsk: BSTU, 2017-p. 108.

[6] Kaplich V. M., Yakubovsky M. V., Bakhur O. V. // Procudings of International Scientific and Practical Conference «Madern Problems of game Management and Protection of Biological Diversity» dedicated to the $90^{\text {th }}$ Anniversary of Prof. S. V. Romanov, Minsk, May16-17, 2017. - Minsk: BSTU, 2017. pp. 111-114.

[7] Kaplich V. M., Yakubovsky M. V., Bakhur O. V. // Procudings of XVI Conference, Ukrainiah fcientific Society of Parasitologists, Lvov, September 18-21 2017. - K.: 2017. - p. 27.

[8] Kaplich V. M., Yakubovsky M. V., Bakhur O. V. // Procudings of International Scientific and Practical Conference dedicated to Memjry of Kozlo P. D., Jctober 9-11, 2017 г. - Minsk: Publisher A. N. Varaksin, 2017.- pp. 43-46.

[9] Kaplich V. M., Yakubovsky M. V., Bakhur O. V. // Forestry: Theses of the 82d Internetional Scientific and Practical Conference, Minsk, February 1-14, 2018. [electronic resource] Minsk: BSTU, 2018. - p. 146.

[10] Yakubovsky M. V., Kaplich V. M., Maszova T. Y., Stepanova E. I., Bakhur O. V. // Proceedings of the Vth International Congress of Veterinary Pharmacologists and Toxicologists «Urgent Problems and Innovations in Modern Veterinary Pharmacology and Toxicology»Vitebsk; 2015a. - pp. 180-183.

[11] Yakubovsky M. V., Kaplich V. M. // Forestry: Theses of the $79^{\text {th }}$ International Scientific and Practical Conference Minsk, February 2-6, 2015 [electronic resource] Minsk: BSTU 2015.p. 107. 